\title{
MAQUIAVEL, A REPÚBLICA E O DESEJO DE LIBERDADE
}

Helton ADVERSE ${ }^{1}$

- RESUMO: O objetivo do artigo é compreender alguns aspectos do republicanismo de Maquiavel concedendo atenção à sua teoria dos humores. Mais especificamente, trata-se de entender qual a natureza do desejo do povo e seu papel na vida política. A principal hipótese deste trabalho é a de que a função que Maquiavel atribui ao povo, o guardião da liberdade, exige, para seu cumprimento, a participação ativa do cidadão nos afazeres cívicos, isto é, sua inscrição no espaço público como agente político. Essa inscrição não pode ser inteiramente compreendida se o desejo que caracteriza o povo carecer de qualquer determinação, isto é, se for tomado somente em uma perspectiva negativa.

- PALAVRAS-CHAVE: Maquiavel; república; liberdade, desejo do povo; vivere civile.

\section{Leituras Republicanas}

Nas últimas décadas tem encontrado grande aceitação a filiação do pensamento de Maquiavel à tradição republicana. Decisivos para tanto foram os trabalhos de Hans Baron" (1966 e 1988), de Quentin Skinner (1996) e de John G. A. Pocock (1975), assim como os de Claude Lefort (1972), e não são poucas as obras recentes que refinam e problematizam a natureza do republicanismo maquiaveliano. Minha intenção, neste artigo, é examinar um aspecto do pensamento político de Maquiavel que - espero - poderá nos ajudar a compreender um pouco melhor a especificidade desse republicanismo. E digo isso porque se a tese de que Maquiavel é um republicano

1 Professor Adjunto do Departamento de Filosofia e do Programa de Pós-Graduação em Filosofia da Universidade Federal de Minas Gerais-UFMG. Artigo recebido em ago/07 e aprovado em nov/07. 
é considerada válida por muitos comentadores, o que caracteriza mais propriamente esse republicanismo está longe de ser consensual. Sendo assim, alguns, como Skinner e Pocock, defendem uma espécie de leitura continuísta da obra de Maquiavel que a situa em um movimento de retomada e reelaboração do republicanismo clássico que tem seu início na Idade Média. Evidentemente, a originalidade de Maquiavel é, nessa perspectiva, se não apagada, bastante mitigada. Por outro lado, Lefort apresenta uma interpretação muito distinta, enfatizando o caráter conflitivo da vida cívica, o que significa conceder grande importância à teoria maquiaveliana dos "humores"2 que perturbam a ordem política. É o modelo de uma "sociedade democrática" que Lefort encontra em seus textos e que confere a eles um raro vigor, uma força explicativa da qual a filosofia política não deve abrir mão se deseja pensar a política na atualidade. ${ }^{3}$

Seja como for, podemos detectar duas "matrizes" na leitura republicana da obra de Maquiavel: a primeira, embora reconheça sua importância para o pensamento político moderno, parece preocupada em chamar a atenção para sua pertinência (o que não quer dizer identificação) ao modelo antigo de republicanismo, ou o chamado "republicanismo clássico". O que caracteriza basicamente esse republicanismo é a convicção de que a liberdade individual não pode ser dissociada da liberdade do Estado, de modo que a participação ativa dos cidadãos nos afazeres cívicos se torna uma exigência, assim como a organização institucional de um espaço em que o poder é exercido pelos membros da comunidade política. Vou deixar de lado aqui o problema das diferenças entre Pocock e Skinner - lembrando apenas que o primeiro lê o republicanismo de Maquiavel em chave aristotélica (ao menos no que concerne à sua compreensão da virtù ${ }^{4}$ ), ao passo que o segundo acredita mais apropriado situá-lo em relação à tradição romana. Com efeito, em trabalhos mais recentes, Skinner (1998 e 2002) vai encontrar na recepção do republicanismo no período do Renascimento e em sua transmissão para a modernidade uma "teoria neo-romana dos Estados livres". 5

2 Umori. Maquiavel toma de empréstimo esse termo da tradição médica hipocrática e galênica que em sua época ainda exercia forte influência. Dentre os vários comentários dessa apropriação, um dos mais recentes e completos é o de M. Gaille-Nikodimov, 2004. Vale lembrar que Maquiavel utiliza como sinônimo para umori, desiderio, isto é, "desejo".

3 E vale ainda lembrar a utilização que Miguel Abensour, 1998, fará dessa leitura.

4 Ménissier (2001, p.243) destaca as limitações dessa interpretação de Pocock.

5 Na verdade, Skinner coloca em xeque a perspectiva dos comunitaristas, especialmente A. MacIntyre, que afirma ser a oposição fundamental na história do pensamento político a que separa o liberalismo individualista e a tradição aristotélica. Ele acredita encontrar em Maquiavel e na "teoria neo-romana" uma terceira alternativa. Isso não significa que Skinner rejeite a oposição in toto: apenas a considera redutora, logo insuficiente para compreender toda a história do pensamento político. Para uma crítica à posição de Skinner, ver P. A. Rahe, 2000. 
A segunda matriz enfatizaria a ruptura de Maquiavel frente à tradição do pensamento político na medida mesmo em que seu pensamento revela o caráter agônico da vida civil, a "indissociável sociabilidade" que une e separa os homens vivendo em um regime político marcado pelas incessantes confrontações das forças sociais. Em suma, teríamos, de um lado, um republicanismo "institucional", na perspectiva do qual a lei e a ordem são não somente os efeitos mas o âmbito próprio da liberdade e, de outro lado, um republicanismo "conflitivo" em que a sociedade é essencialmente aberta e o espaço público para a ação livre é concebido em sua instabilidade estrutural; nesse caso, mais do que a ocasião da liberdade, as instituições republicanas são constantemente relançadas por ela.

Estou ciente de que a distinção entre as leituras republicanas de Maquiavel que apresento é por demais esquemática e que desconsidera uma série de nuances em uma matriz e outra. Mesmo assim vou mantê-la porque dessa forma posso mais facilmente atingir meu objetivo. Acredito que uma análise do republicanismo de Maquiavel tem de enfrentar os dois pontos destacados em cada uma das correntes interpretativas: o institucional e o conflitivo e a noção que permite articulá-los é precisamente a de liberdade. Para realizar essa articulação, proponho que concedamos especial atenção à "teoria dos humores" em Maquiavel.

\section{A Oposição Fundamental}

São inúmeras as referências na obra de Maquiavel aos desejos (ou "humores") opostos que constituem a dinâmica pulsional de toda civiltà. Vale destacar, porém, três delas: a primeira, no capítulo IX de O príncipe; a segunda, no capítulo 4 do livro I dos Discursos sobre a primeira década de Tito Lívio; ${ }^{6}$ e a última no capítulo 1 do livro III da História de Florença.

O capítulo IX de $O$ príncipe trata de uma figura anfíbia, espécie de oxímoro que Maquiavel denomina "principado civil", uma mistura de principado com república que mantém sua ambigüidade até mesmo no modo de ascensão ao poder: não é nem por Fortuna nem por virtù, mas por uma "astúcia afortunada" que um cidadão torna-se o governante de sua pátria. Alguns comentadores, como P. Larivaille (2001), lerão esse capítulo em uma chave republicana, encontrando na dinâmica política própria de uma república as condições para a emergência dessa estranha forma de governo ${ }^{7}$ e é

6 De agora em diante me referirei a essa obra apenas como Discursos.

7 Imprescindível, também, a consulta aos dois artigos de G. Sasso, 1987 e 1997, sobre esse capítulo. Para um comentário mais recente do tema ver T. Ménissier, 2006. 
precisamente esse o ponto sobre o qual eu gostaria de me deter. O traço distintivo de um principado civil é que aquele que aí exerce o poder o adquire pelo "favor dos outros cidadãos" (Maquiavel, 1993a, p.271). Esse favor, esclarece Maquiavel, pode ser ou do povo (populo) ou dos grandes (grandi):

Porque em toda cidade se encontram estes dois humores diversos; e nasce disso que o povo deseja não ser comandado nem oprimido pelos grandes, e os grandes desejam comandar e oprimir o povo; e desses dois apetites diversos nascem nas cidades um dos três efeitos: ou principado ou liberdade ou licença. (Maquiavel, 1993a, p.271)

A ordem política na cidade será definida então a partir da oposição entre os desejos que animam seus cidadãos. Essa passagem me permite fazer duas considerações que creio relevantes para situarmos o problema do republicanismo de Maquiavel: a primeira diz respeito à natureza dos humores; a segunda ao efeito de seu confronto. No que concerne a este último, vale observar que a "liberdade" à qual Maquiavel faz referência é o regime republicano. Quanto à natureza dos humores, o que podemos apreender imediatamente é que o desejo dos grandes é positivo porque determinado, ao passo que o desejo do povo, indeterminado, seria negativo: antes de mais nada, o povo exige apenas "não ser oprimido" (Maquiavel, 1993a, p.272). Para muitos comentadores, isso significa o esvaziamento do desejo do povo de todo conteúdo político ou, ainda, significa que o povo "não quer saber nada do poder, e não se preocupa com as condições necessárias para o estabelecimento dessa não-opressão" (Sfez, 1999, p.182). Sfez apóia-se na leitura de Lefort, o qual insiste no caráter universal, indeterminado do desejo do povo. Na corrente interpretativa que remonta a Leo Strauss, da negatividade desse desejo é deduzida a passividade do povo. ${ }^{8}$ Harvey Mansfield, por exemplo, afirma o seguinte:

Para Maquiavel, somente alguns homens são políticos, e eles governam em qualquer regime, não importa como seja chamado. O povo não deseja governar e quando parece governar, está sendo manipulados por seus líderes. Ele é matéria sem forma, corpo sem cabeça. Uma vez que não pode governar, o regime é sempre o governo de um príncipe ou de príncipes. (Mansfield, 1996, p.237)

Para engrossar a fileira, cito ainda um leitor de Maquiavel não pertencente a nenhuma dessas tradições interpretativas, mas cuja obra é extremamente influente. Trata-se de M. Foucault que, no curso ministrado no Collège de France em 1978, diz o seguinte: "Para Maquiavel, no fundo, o

8 O que, a meu ver, é confundir o desejo do povo com a classe social onde ele emerge. 
povo era essencialmente passivo, ingênuo, ele tinha de servir de instrumento ao príncipe, sem o que ele servia de instrumento aos grandes" (Foucault, 2004, p.277).

Não estou preocupado aqui em fazer o trabalho do especialista e mostrar as falhas dessas interpretações. O mais importante é fazer notar que a conseqüência do esvaziamento político do desejo do povo é inequívoca: as conviç̧ões republicanas de Maquiavel ficam sob suspeita; somos obrigados a vê-lo como o pensador da dominação. Logicamente impecável é, portanto, a leitura de Mansfield: o regime é sempre principado. Se quisermos negar a conclusão, devemos então negar as premissas.

\section{II.I. Positivar o desejo do Povo}

No texto de $O$ príncipe encontramos elementos que nos permitem suspeitar de que o humor popular não pode ser desprovido de conteúdo político. O capítulo V, por exemplo, reforça a idéia de que os homens se apegam não somente a seus interesses pessoais, mas a um modo de vida político um ethos político - do qual não abrem mão complacentemente. Esse ethos é o da liberdade. Quero marcar, então, o primeiro encontro entre o desejo do povo e a liberdade (ao longo deste trabalho não farei outra coisa a não ser aprofundar essa relação). Esse ethos político da liberdade não pode ser compreendido apenas negativamente porque envolve um princípio de ação. Com efeito, Maquiavel fala, nessa passagem, de rebelião. O príncipe que deseja dominar uma cidade acostumada a viver libre (entenda-se: uma república) se vê diante de uma tarefa extremamente árdua em que seu poderio está mesmo colocado em xeque: ou ele a destrói ou é destruído por ela por meio da rebelião (Maquiavel, 1993a, p.264). E o que leva os homens a se rebelarem? Seus interesses privados (usufruir de sua propriedade em segurança)? Pode ser; não vamos excluí-los. O texto, porém, diz ainda outra coisa:

(...) quem se apodera (chi diviene padrone) de uma cidade acostumada a viver livre e não a destrói, espere ser destruído por ela: porque sempre tem por refúgio, na rebelião, o nome da liberdade e suas ordens (ordini) antigas, as quais nem a distância do tempo nem os benefícios fazem esquecer. (Maquiavel, 1993a, p.264)

A rebelião é resistência ativa e evidencia a ligação entre cidadão e cidade sob a forma do engajamento. Maquiavel deixa bastante claro que esse comprometimento com a civiltà ultrapassa o limiar estabelecido pelos bens pessoais. Pode-se comprar a liberdade de alguns cidadãos com a concessão de cargos públicos, mas em seu conjunto eles não aceitam a barganha. E isso não porque não haveria cargos e magistraturas para todos os cidadãos, 
e sim porque está em questão a conservação de um bem que é comum: a própria liberdade.

Mas que espécie de bem é esse? Sem desejar retomar a discussão acerca do conceito de liberdade, somente faço lembrar que em Maquiavel podemos com segurança distinguir, no mínimo, duas acepções que, por sua vez, estão intimamente ligadas. A primeira é basicamente negativa e se refere à relação de uma cidade com suas rivais. O que está em jogo, nesse caso, é sua independência frente a elas. ${ }^{9}$ A segunda acepção concerne à ordem interna da cidade e à sua vida institucional: viver livremente significa viver sob leis que, com maior ou menor participação popular, são elaboradas pelos próprios cidadãos. Tenho a impressão, porém, de que podemos obter uma visão mais detalhada do problema da liberdade se nos detivermos um pouco mais nesse texto fazendo um cotejamento com Discursos, II, 2.

Este capítulo trata da obstinação dos romanos na defesa de sua liberdade. Não apenas dos romanos, é verdade. Todo povo acostumado a viver livremente, isto é, sem um senhor que o subjugue, é extremamente feroz na luta contra o adversário, o que faz enaltecer a conquista dos romanos nos séculos de expansão de seu domínio territorial e político. A liberdade fornece também a chave explicativa do próprio expansionismo, uma vez que uma cidade livre está mais inclinada a dominar as demais porque a riqueza conquistada torna-se bem comum: "a experiência mostra que as cidades nunca crescem em domínio nem em riquezas, a não ser quando são livres" (Maquiavel, 1993b, p.148). Isso significa que em uma cidade livre a distância entre a grandeza da pátria e o interesse individual é fortemente encurtada. Para ser mais rigoroso, está em questão uma identificação entre o bem da cidade e o bem do cidadão. O que proponho é interpretar essa identificação no sentido forte, ou seja, não se trata somente de uma convergência de interesses na qual atende-se o interesse público porque é a única maneira de garantir a satisfação do interesse privado, embora essa espécie de cálculo não seja estranha a Maquiavel. Acredito que Maquiavel esteja falando da constituição de um objeto de interesse comum: o que em diversas ocasiões ele chama de pátria ${ }^{10}$ A pátria é a cidade a que se pertence e, nesse sentido, o termo é politicamente neutro, isto é, vale para a república ou para o principado. Mas a pátria envolve também "um modo de vida e uma cultura", e, no caso de uma república, "é um particular modo de vida e uma cultura que se fundam sobre os valores da liberdade e da igualdade civil" (Viroli, 2001, p.39). ${ }^{11}$ Em vez de encontrar subjacente em Discursos, II,2 o

9 Para uma análise recente do tema ver M. Hörnqvist, 2004.

10 O termo é utilizado várias vezes por Maquiavel, mas aparece em maior número nos Discursos.

11 A respeito vale a pena ver também Y. C. Zarka, 2001. 
desejo de adquirir, como têm feito alguns comentadores que lêem o republicanismo de Maquiavel como essencialmente predatório (Fischer, 2000; Hörnqvist, 2004; Sullivan, 2004), ${ }^{12}$ desconfio que essa passagem nos indique algo diferente acerca da natureza do vínculo entre cidadão e cidade. Não desconsidero a relevância do desejo de adquirir que de fato Maquiavel atribui aos homens, ${ }^{13}$ em contrapartida, talvez essa grade antropológica não seja a mais adequada para entender seu pensamento político, muito menos podemos com ela fazer a escanção de todos os passos de seu republicanismo. O que quero dizer é que se estendermos o desejo de adquirir a todo o corpo social, isto é, se o reconhecemos como o desejo essencial de todo o corpo social e transformamos a república em animal predador, então o desejo do povo termina por igualar-se ao dos grandes, com a pequena diferença de que seria domesticado por causa do reconhecimento, da parte dos cidadãos, de que não podem satisfazer livremente suas vontades de modo individual, por impotência. É o argumento de Cálicles que retornaria, um pouco edulcorado, é verdade, mas guardando ainda seu elemento corrosivo. Teríamos, nesse caso, um desejo só (o de adquirir) que constituiria o fundo comum para todos os desejos na cidade. Ora, não estou convencido de que o texto de Maquiavel nos autoriza a tirar essa conclusão. Se formos ao capítulo 37 do livro I dos Discursos, veremos que um dos motivos que levaram à decadência de Roma foi precisamente a identificação do desejo do povo com o dos grandes:

(...) a plebe romana não se contentou em obter garantias contra os nobres com a instituição dos tribunos, desejo ao qual foi forçada por necessidade; pois ela, tão logo obteve isso, começou a lutar por ambição e a querer dividir cargos (onori) e patrimônio (sustanze) com a nobreza, como coisa mais valiosa para os homens. (Maquiavel, 1993b, p.119)

Sendo assim, o desejo de adquirir (inerente a todo ser humano), ao qual Maquiavel havia feito alusão algumas linhas antes da citação acima, tem de ser regulado, sob o risco de rompimento do tecido político. E em que consiste mais precisamente essa desregulagem? Essa desregulagem é a "má tradução", ${ }^{14}$ a má positivação do desejo do povo e pode ser considerada também do ponto de vista da memória porque se trata de uma espécie de esquecimento (do que falarei mais adiante). Para compreendermos melhor esse ponto, vale a pena voltar a Discursos, II, 2.

12 Ver M. Fischer, Well-ordered license. On the unity of Machiavelli's thought. New York: Lexington Books, 2000; M. Hörnqvist, Machiavelli and empire, op. cit. e V. Sullivan, Machiavelli, Hobbes and the formation of a liberal republicanism in England. Cambridge: Cambridge University Press, 2004.

13 Ver, por exemplo, Discursos, I, 37.

14 Tomo de empréstimo essa expressão de M. Gaille-Nikodimov, 2004, p.44. 
Quando o povo "deseja bem"? Os povos que vivem sob liberdade, diz Maquiavel, são os de população mais numerosa porque a vida sob esse regime é mais aprazível e segura, o que somente é possível se atingido um certo nível de igualdade social e política. Neste caso, "cada um, de bom grado, tem a prole que acredita poder sustentar, sem temer ser despojado de seu patrimônio" (Maquiavel, 1993b, p.150). Até aí, o texto de Maquiavel serve a contento àqueles que destacam elementos liberais de seu pensamento. Em seguida, porém, diz: "ademais, todos sabem muito bem que não só nasceram livres, e não escravos, como também que, se tiverem virtù para tanto, poderão tornar-se príncipes" (idem). Se tivermos em mente todo o argumento do capítulo, o que isso quer dizer, a não ser que a garantia de participação na vida pública é um bem considerável, com o qual não se pode transigir? Esta perspectiva que avanço ainda está sujeita a críticas, porém. O que me autorizaria a inferir que "tornar-se príncipes" seria diferente de exercer domínio sobre os outros cidadãos? Nesse caso, não despontaria mais uma vez um desejo perfeitamente identificado com o interesse pessoal?

Para refutar essa objeção, é necessário ir a outra passagem dos Discursos na qual poderemos apreendermos melhor em que consiste a "positivação" do desejo do povo e o modo segundo o qual ela opera na vida política. Refiro-me ao famoso capítulo 4 do livro I, no qual Maquiavel apresenta uma de suas teses mais polêmicas, a saber, a de que a liberdade romana encontrava sua causa nos tumultos envolvendo o senado e a plebe; é nessa dissensão fundamental que puderam se originar as boas leis de Roma. Por isso, Maquiavel censura aqueles que não perceberam o verdadeiro significado político dos tumultos e que não consideraram que "em toda república há dois humores diferentes, o do povo e o dos grandes, e que todas as leis que se fazem em favor da liberdade nascem da desunião deles" (Maquiavel, 1993b, p.82). Sobre quais fundamentos se assenta essa afirmação? No final do capítulo temos a resposta: a agitação popular em Roma obrigou os grandes a reconhecer a plebe como sujeito político; a criação dos tribunos foi a resposta institucional para atender à demanda do povo. Dizendo de outra maneira, as leis em Roma eram benéficas à liberdade pública porque em sua criação e instituição o elemento popular, por meio dos tribunos, não estava alheio. Daí podemos iniciar duas série de considerações, entrelaçadas com as anteriormente realizadas. A primeira relança o problema da liberdade; a segunda o dos humores.

O capítulo seguinte dos Discursos examina a questão: quem deve ser o guardião da liberdade, o povo ou os grandes? O bom senso aconselha a dar guarda de uma coisa àquele que tem menos desejo de dela se apoderar. Sendo assim, é ao povo que cabe a guarda da liberdade, uma vez que seu desejo é essencialmente o de não ser dominado, o que quer dizer - em termos positivos utilizados pelo próprio Maquiavel - que os plebeus (ignobili) 
têm "maior vontade de viver livres" (Maquiavel, 1993b, p.83). Mas o que significa, praticamente, estar imbuído da tarefa de guardar a liberdade? No nível institucional, significa dispor de autoridade para, por meio de seus representantes, exercer importantes magistraturas e, no exercício dessas magistraturas, o povo não deverá visar a dominação. Em Roma, a maior delas (ao menos a de maior prestígio) era o consulado, sendo um dos cônsules (e mais tarde os dois) eleito pela plebe e podendo ser ele próprio originado dela. Além disso, cabia ao tribunato da plebe defender os interesses do povo e fazer frente aos sempre possíveis excessos do senado. O tribunato detinha o poder de vetar as leis. Ser guardião da liberdade implicava, portanto, o direito de exercer o poder, seja por via representativa, seja por via direta. O reconhecimento (ou concessão) desse direito satisfaz, no âmbito institucional, o desejo de participação na vida pública.

Podemos ver então que o desejo de não ser dominado está longe de poder ser reduzido ao negativo do desejo de dominar, como se tratasse de A e não-A. Caso se tratasse de uma contrariedade absoluta, a dinâmica política se encerraria uma vez afirmado um dos desejos, ao passo que Maquiavel nos diz algo diferente: as inimizades entre povo e plebe perduraram enquanto Roma alcançava sua grandeza. É porque não há contrariedade absoluta que os dois desejos podem então se afirmar e os conflitos manter rigorosa a vida política. Mas isso não quer dizer que um desejo possa se afirmar independentemente do outro: eles remetem um ao outro indefinidamente. Seguindo Gaille-Nikodimov (que nesse ponto se apóia em P. Macherey), a relação entre esses desejos é esclarecida quando pensamos que a unidade a que eles remetem não é anterior à sua oposição: eles não fazem parte de um todo. Antes constituem uma unidade na sua diferença:

A identidade dos contrários, é também sua exclusão mútua: ela não é dada por e em sua reunião, sua adição ou sua fusão, mas através de sua divisão. Ela não é então a identidade originária de uma essência que se afirmaria a priori em sua relação a si; mas ela é essa singular 'unidade' que faz com que um contrário não exista jamais em si mesmo ou por si mesmo sem que a existência de 'seu' contrário não esteja aí de antemão implicada, de maneira intrínseca e não extrínseca. Diríamos, então, que a identidade não é outra coisa além da diferença. (Macherey, citado por Gaille-Nikodimov, 2004, p.48-9).

Isso nos permite compreender também como o desejo de não ser dominado pode se traduzir em uma exigência de participação política sem se igualar ao desejo de dominar, mas acionando-o mais uma vez como aquilo que limita e que é limitado por esse próprio desejo (o de não dominar). Somente assim torna-se possível esclarecer como o desejo do povo pode efetivamente refrear o dos grandes. Quando estamos no domínio dos humores, só o positivo pode se contrapor ao positivo; de outro modo, haveria sobre- 
posição e conseqüente anulação de um e outro. O resultado desse processo costuma ser ou a morte da civiltà ou seu esgarçamento. A leitura do início do livro III da História de Florença pode lançar alguma luz sobre o problema.

\section{Os Humores se Misturam}

O livro III da História de Florença vai mais uma vez apresentar a divisão entre humores presentes em toda cidade. Contudo, Maquiavel a coloca sob uma outra luz, chamando a atenção para seus efeitos negativos. Nada mais coerente, pois se trata agora da história de uma cidade que, embora de vocação republicana, abortou inúmeras vezes a possibilidade de estabelecimento de um autêntico vivere libero:

As inimizades graves e naturais que existem entre os homens populares e os nobres, causadas por estes quererem comandar e aqueles não obedecer, são as razões de todos os males que surgem nas cidades porque todas as outras coisas que perturbam as repúblicas têm seu alimento nessa diversidade de humores. Isso manteve Roma desunida; e isso, se é lícito igualar as coisas pequenas às grandes, manteve Florença dividida, sendo que produziu efeitos diversos em uma e outra cidade. Porque as inimizades que existiram no princípio em Roma entre o povo e os nobres se definiam disputando e, aquelas de Florença, combatendo; as de Roma terminavam com uma lei, as de Florença com o exílio e com a morte de muitos cidadãos; as de Roma sempre aumentavam a virtù militar, as de Florença a extinguiam; as de Roma conduziam aquela cidade de uma igualdade dos cidadãos a uma grandíssima desigualdade, as de Florença a reduziram de uma desigualdade a uma espantosa igualdade. Essa diversidade de efeitos foi causada pelos fins diversos que tiveram esses dois povos: porque o povo de Roma desejava gozar as supremas honras com os nobres; o de Florença combatia para estar só no governo, sem que os nobres aí participassem. (Maquiavel, 1993c, p.690)

Nessa nova apresentação dos conflitos na cidade vemos se delinear com mais precisão a teoria maquiaveliana dos humores. Em primeiro plano, destaca-se outra vez o desfecho institucional que a divisão entre os desejos encontrou em Roma, ao passo que em Florença ela enfraqueceu o corpo político devido à impossibilidade de se resolver as diferenças por meios "ordinários". Em Roma, as divergências se resolvem "disputando", enquanto em Florença os cidadãos "combatem". "Disputar" e "combater" são dois meios inteiramente distintos para se resolver as discórdias: o primeiro envolve os mecanismos institucionais, ao passo que o segundo consiste sempre em uma ação de caráter privado. Sendo assim, "disputar" implica uma universalização na medida em que os adversários estão comprometidos com um mesmo conjunto de regras, logo envolve algum grau de consenso, daí a referência que faz Maquiavel à lei. Por outro lado, "combater" é sempre da or- 
dem da particularidade e os adversários se enfrentam em campos opostos, um lutando para sobrepujar o outro. ${ }^{15} \mathrm{~A}$ universalidade, nesse caso, somente será atingida como expansão da particularidade ou como homogeneização: o que significa a eliminação do outro. Para Maquiavel, é esse o mal que acomete Florença: aí a divisão origina "seitas", ${ }^{16}$ impedindo o fortalecimento do tecido social e a formação de uma comunidade política verdadeiramente republicana. Acompanhando esses efeitos das divisões em um e outro caso estão o aumento ou a diminuição da virtù e - o que me interessa mais - a definição da igualdade e desigualdade entre os cidadãos.

Vou deixar de lado, por enquanto, o problema da virtù e passo a comentar essa aparentemente espantosa exaltação da desigualdade romana. Se lembrarmos o capítulo 55 do livro I dos Discursos, a igualdade é uma das condições para o estabelecimento do regime republicano. Maquiavel não se refere, nesse trecho, a uma igualdade absoluta que apagaria as diferenças sociais e econômicas, mas a uma certa homogeneidade no modo de vida dos cidadãos e a seus efeitos políticos. Mais ainda, o econômico não parece constituir um objeto próprio de investigação para Maquiavel: quando seu interesse se dirige a questões dessa natureza sempre estará presente a dimensão política, como vemos já nos escritos de chancelaria. ${ }^{17}$ Como quer que seja, a igualdade que, segundo o capítulo 55 de Discursos, I, caracteriza o vivere libero não é concebida em termos puramente econômicos, ou seja, ela não pode ser desvinculada de seus efeitos políticos. Como observou Lefort, ela deve ser pensada em sua "relação simbólica" (Lefort, 1978, p.227), vale dizer, "onde reina a igualdade, é, de algum modo, o campo social que se torna igual a si mesmo ou, poderíamos ainda traduzir, homogêneo. Aí, e somente aí, a divisão se manifesta como puramente social e as desigualdades que a acompanham são apenas sociais" (idem).

Não estou seguro, porém, de que possamos resolver assim o problema da igualdade e desigualdade nessa passagem das Istorie. Se não precisamos descartar o elemento econômico, não podemos nos apoiar sobre isso pelo simples fato de Maquiavel não fazer qualquer referência explícita a ele.

15 Uma aproximação com Kant não me parece de todo descabida. Tenho em mente a antinomia do juízo estético. Não podemos ver uma semelhança na relação entre streiten e disputieren e disputare e combattere? Com efeito, os primeiros membros dos pares consistem em um raciocinar partindo de princípios aceitos universalmente sem visar qualquer resolução objetiva. Disputieren e combattere, por sua vez, acarretam uma decisão, logo uma determinação, seja do conceito, seja do interesse sob a forma privada. Ver I. Kant, Kritik der Urteilskraft, §§ 56-57.

16 Sobre os efeitos nefastos das "seitas", ver o livro VII das Istorie fiorentine. Ver também G. Bock, 1990

17 Ver especialmente o Ritratto di cose de Francia, o Rapporto delle cose della Magna e o Ritratto delle cose della Magna. 
Talvez possamos contornar a dificuldade reduzindo a igualdade a seu aspecto político, aceitando a suposição de que se trata de uma igualdade conquistada, aquela que encontramos em Roma e que basicamente consiste na abertura do espaço político aos membros da plebe, como Maquiavel nos relata em Discursos, I, 4 e 5. De qualquer maneira, independentemente da relevância que concedamos ao elemento econômico, os efeitos da igualdade em uma república se fazem sentir no nível político como desigualdades e isso nos ajuda a compreender por que Maquiavel faz seu elogio: os tumultos podem operar seu efeito benéfico sobre a cidade quando um desejo não supera o outro, o que quer dizer manutenção da desigualdade sobre um "fundo" de igualdade, ou manutenção da igualdade na limitação das desigualdades. Outra vez é a clivagem fundamental, a oposição entre os desejos que reaparece. Mas logo em seguida Maquiavel acrescenta algo que parece turvar a limpidez da distinção entre os desejos: ela, a distinção, está longe de ser absoluta porque em Roma (retomo a citação feita um pouco acima) o povo "desejava gozar as supremas honras juntamente com os nobres" (Maquiavel, 1993c, p.690). Costuma-se entender esse "juntamente" como indicando o fato de que em Roma nobres e povo "disputavam" no espaço público e aí, por meio institucionais, encontravam um canal para desafogar seus humores e contemporizar suas diferenças. Não coloco em xeque a pertinência dessa interpretação. Por outro lado, se enfatizássemos o desejo de honraria e entendêssemos o "juntamente" indicando semelhança não reintroduziremos a igualdade, agora em outro registro? A igualdade seria então decorrente da identidade daquilo que é desejado; igualdade perigosa (como veremos logo em seguida) e não surpreende a sombra de César se projetando sobre o dia da liberdade romana, isso porque o desejo do povo, positivado como desejo de honras, esteve na origem da grandeza e da decadência de Roma. Quando o povo "vencia" os grandes, sua vitória resultava em benefício para toda a cidade, pois, podendo participar da "administração dos magistrados, dos exércitos e dos impérios com os nobres que já ocupavam esses postos" (idem), o povo adquiria virtù, fazendo aumentar a potência da cidade. Mas essa mesma virtù transformou-se em "soberba" e Roma não pôde se manter sem que um "príncipe" a governasse (idem, p.690-1).

Essa soberba tem de ser compreendida à luz dos eventos comentados em Discursos, I, 37, que levaram à ruína da república. Nas disputas originadas pela retomada da lei agrária assistimos à corrupção da virtù do povo que passa, como já vimos, a "lutar por ambição"(Maquiavel, 1993b, p.119). Maquiavel introduz aqui uma modulação (que antes havíamos formulado em termos do bom e mau desejo) esclarecendo que a identidade do objeto dos desejos não implica identidade na maneira de desejar. O povo deseja bem as honrarias quando é levado a conquistá-las por necessidade. Portanto, essa identidade é artificial; uma vez desaparecido o aguilhão da neces- 
sidade, uma vez o povo imerso no ócio, segue-se a ruína. ${ }^{18}$ Essa artificialidade é sinal da plasticidade do desejo do povo que, exatamente por ser em sua essência indeterminado, pode ser bem ou mal determinado. O desejo dos grandes, em princípio já determinado, é sempre idêntico a si. Por isso Maquiavel pode atribuir a responsabilidade pela grandeza ou decadência ao desejo do povo, como vemos também no livro III das Istorie. Se o povo passa a desejar como os grandes, isto é, quando se torna ambicioso, preocupado apenas em satisfazer seu próprio interesse, em detrimento do bem comum, então a república está com os dias contados. Desfecho catastrófico da oposição fundamental: o humor do povo se igualou ao dos grandes.

Maquiavel mostra que a grande diferença nos destinos políticos de Roma e Florença se deve à inclusão, no primeiro caso, de povo e nobres no espaço público e, no caso de Florença, sua degradação está ligada à exclusão de uma parte ou outra dos cidadãos, exclusão que terminava em perseguições, exílios e mortes. O combate entre povo e grandes originava leis que não visavam a utilidade comum e sim favoreciam os "vencedores" ( $\mathrm{Ma}$ quiavel, 1993c, p.690). Onde estão a desigualdade e a igualdade em Florença? A desigualdade se encontra na própria divisão social e a igualdade no desfecho do confronto. A cidade, portanto, se encontra em situação semelhante à de Roma à beira da guerra civil: o povo, desprovido de virtù, deseja o mesmo, do mesmo modo que os grandes, a ponto de apagar assim as distinções entre eles:

Mas em Florença, vencendo o povo, os nobres ficavam privados das magistraturas e, querendo readquiri-las, lhe era necessário, com seu proceder (i governi), com o ânimo e com o modo de viver, não somente ser semelhantes ao povo, mas parecer. Daí provinha as mudanças nas insígnias, as mutações dos títulos das famílias que os nobres faziam para parecer povo. (idem, p.690-1)

Os nobres semelhantes ao povo: dois se fez um. Fez-se um na má positivação do desejo do povo, identificado com o dos nobres. Estes tornaram-se parecidos com o povo porque o povo tornou-se parecido com os nobres: quando a cidade chega a esse ponto, não há mais vida política. Mas é necessário examinar mais de perto essa possível identificação entre os humores.

\section{Necessidade e Liberdade}

Uma objeção que pode ser feita é: na dinâmica política, quando o desejo do povo é positivado, a diferença entre ele e o desejo dos grandes é apenas

18 Como vemos no início do livro V das Istorie fiorentine. 
de modo? Seu objeto é realmente o mesmo? Acredito que sim e não. Para ser o guardião da liberdade, como diz Maquiavel, é necessário que o povo queira alguma participação na vida política, o que significa o exercício de magistraturas. Nessa determinação de seu desejo originariamente negativo, ele rivaliza com os grandes. Mas na medida em que se trata mesmo de uma determinação ela é sempre posterior à indeterminação originária. Nesse sentido, o desejo do povo continua sendo o de não ser oprimido e é ele que deve subordinar o desejo positivado. Quem quer os fins, deve também querer os meios. A corrupção torna-se uma ameaça real quando o exercício prolongado dos meios faz o povo esquecer o fim que ele originalmente deseja.

A tarefa de fazer o povo se lembrar do objeto originário de seu desejo faz necessário um expediente que Maquiavel examina em Discursos, III, 1: a refundação. De tempos em tempos (no máximo a cada dez anos, para ser mais exato), é imprescindível despertar no espírito dos cidadãos a virtù adormecida pela estabilidade política. Esse "retorno aos princípios" pode ser um dispositivo constitucional (intrínseco) ou acontecer por causa de um evento "independente de tal ordenação" (Maquiavel, 1993b, p.195), isto é, extrínseco. Antevejo aqui mais uma objeção: Maquiavel não deixa dúvidas de que esse "retorno aos princípios" é antes de mais nada fazer o povo experimentar novamente o terror, o medo que acompanham toda fundação de um estado, como vemos no caso das execuções (idem, p.196). Como conciliar essas paixões com o desejo de não ser oprimido? Esta pergunta tem como pano de fundo a oposição entre necessidade e liberdade, e é examinando esse problema que conseguirei concluir este trabalho.

Se nos ativermos a Discursos, III, 1, veremos que reavivar o medo e o terror não é o único expediente para fazer os cidadãos mais uma vez respeitar as ordenações da república. É verdade que o receio de ser punido torna os homens obedientes à lei (idem, p.196), mas igualmente efetivo é o exemplo de virtù dos grandes cidadãos:

Os homens que, em Roma, particularmente, produziram tais bons efeitos foram Horácio Cocles, Cévola, Fabrício, os dois Décios, Régulo Atílio e alguns outros que, com exemplos raros e virtuosos, produziam em Roma quase o mesmo efeito que produzem as leis e as ordenações. (idem, p.196)

Esses ilustres romanos têm em comum a disposição ilimitada a se sacrificar pela pátria, um devotamento à liberdade romana comprovado nas campanhas militares. São também exemplos de coragem: ${ }^{19}$ as paixões que

19 Especialmente Horácio Colces e Mucio Cévola que deram mostras de sua virtù na guerra contra os etruscos. Ver os capítulos 10 e 12 do livro II da História romana de Tito Lívio, 1995. 
eles evocam são em tudo contrárias ao medo e terror. Se lembrarmos que em Discursos, III, 21, Maquiavel afirma que duas coisas principalmente fazem os homens agir, o temor e o amor (Maquiavel, 1993b, p.227), então nos deparamos, no momento de renovação da fundação, com os dois privilegiados motivos para a ação. Sendo assim, as execuções e os exemplos revitalizam a república renovando a seiva que alimenta os espíritos de seus cidadãos e não é difícil agora perceber a ligação com o problema da necessidade e da liberdade. De sua parte, o medo não pode ser desvencilhado do mal. Como paixão prospectiva, está ligado à consciência da possibilidade do mal. Ele impulsiona os homens para evitar a concretização do mal, logo eles agem por necessidade. Não podemos desconsiderar a importância dessa última na regulação do desejo do povo, como vimos quando comentamos Discursos, I, 37. Vale também recordar que seu poder de manter os espíritos fortes, de manter a virtù, é um tópico abordado bem no começo do livro I, no primeiro capítulo que trata da fundação das cidades. Maquiavel não vai demorar muito para daí extrair a lição de que os homens somente fazem o bem por necessidade (Maquiavel, 1993b, p.81-2). Mas, se nos voltarmos para o amor, talvez essa não seja a última palavra.

Discursos, III, 22, oferece dois excelentes exemplos de como o amor pode influir sobre os homens, levando-os a obedecer à lei. Valério Corvino e o veneziano Vettore Pisanim, amados por seus comandados, são capazes de mantê-los em ordem e evitar dissensões. Essa eficácia do amor, contudo, não deixa de ser problemática para uma república, uma vez que o vínculo entre comandante e comandados rivaliza com o amor pelo bem comum (Maquiavel, 1993b, p.229), de modo que o amor pode estar a serviço da ambição privada. Por esse motivo, o amor que os heróis romanos listados em Discursos, III, 1, devem despertar entre os cidadãos difere do laço pessoal que une soldados de uma milícia e seu capitão. A devoção de que os heróis dão mostra é o amor pela pátria. ${ }^{20}$

A partir de Discursos, III, 1, somos obrigados a deduzir que caso essa paixão desapareça da cena pública, o destino da república estará selado. Sem ela será difícil impedir a sobreposição dos interesses particulares sobre o interesse público porque (e isso me parece ser o mais importante) entre essa paixão e a virtù há uma grande proximidade, assim como entre ambas e a liberdade. Quando defendia a ponte Sublicius, Horácio Cocles dirigia insultos aos etruscos, chamando-os de "escravos de reis despóticos"

20 Com a expressão amore della patria, presente em profusão em seus textos políticos (mas não em O príncipe), Maquiavel retoma um tema do republicanismo romano, como podemos ver em Cícero, por exemplo, no De officiis, I, 57 (o amor que envolve todos os demais: sed omnes omnium caritates patria une complexa est) e 58, ou ainda, De republica, I, 3 e VI, 16. 
e acusando-os de ter esquecido sua antiga liberdade e desejando agora atacar a dos outros (Tito Lívio, 1995, p.172). A associação entre pátria e liberdade já havia sido estabelecida nesse trabalho; faltava somente reforçá-la com a introdução dessa paixão. Resta examinar que relação há entre o amor pela pátria e o desejo do povo.

Proponho que se entenda o amor pela pátria como a forma afetiva do desejo de liberdade. Isso significa que amar a pátria é tomar a coisa pública ela mesma como objeto de desejo e que os interesses privados, como querem alguns comentadores, ${ }^{21}$ não podem recobrir toda a gama de motivações para a ação. Mais ainda, a lógica segundo a qual ao defender o bem comum (identificado com a liberdade) os cidadãos estão defendendo seus próprios interesses revela suas limitações: não há dúvida que os homens, ao sairem em defesa da coisa pública, sempre consideram seu benefício pessoal, mas no republicanismo maquiaveliano não podem operar apenas com essa lógica porque a conservação do vivere libero exige que se tome a coisa pública como um objeto a ser desejado por ele mesmo, o que é o mesmo que dizer que o bem comum tem de ganhar alguma substância para os cidadãos. Esse é propriamente o normativismo presente no pensamento de Maquiavel e o sentido do termo virtù quando referido ao povo.

Talvez essas considerações soem muito abstratas para um pensamento como o de Maquiavel, sempre calcado no evento, sempre atento à veritá effettuale. Mas digo que o objeto desse amor é bastante concreto: são as instituições, são as leis, é o próprio espaço político em que os homens agem. Sei também que isso soa estranho à "antropologia" maquiaveliana, segundo a qual os homens estão por natureza inclinados a amar não o próximo, mas aquilo que lhe está próximo, aquilo que lhe proporciona benefício. A essa antropologia respondo com a história e digo que o cidadão é sim capaz de amar sua cidade mais do que a própria alma. ${ }^{22}$ Respondo também com uma verdade efetiva da política, lição tão bem compreendida por Hannah Arendt: para se fazer política deve-se estar disposto a sacrificar mesmo a própria alma. Na linguagem de Maquiavel, significa estar disposto a "entrar no mal", exigência incontornável para todo aquele que deseja realizar grandes coisas.

Não estou desconsiderando, portanto, o peso da necessidade na concepção política maquiaveliana. Mas creio ser igualmente necessário cir-

21 Dentre os mais recentes, ver Nadeau, 2003.

22 Sobre alguns cidadãos de Florença que, no conflito contra o Papa Gregório XI, não temeram a excomunhão, Maquiavel escreve: "tanto aqueles cidadãos estimavam então mais a pátria do que a alma". (Maquiavel, 1973c, p.696). Desnecessário lembrar que o próprio Maquiavel utiliza essas palavras, referindo-se a si mesmo, em uma muito conhecida carta a Guicciardini. 
cunscrever o âmbito em que a necessidade atua. Duas passagens, muito conhecidas, exigem comentário: o primeiro parágrafo do capítulo 15 do Príncipe e o cap. 3 de Discorsi, I. A referência a uma natureza humana aí ocupa um lugar especial na medida em que a perfeição, ou melhor, o ideal de perfeição é abandonado: a maldade humana torna necessária a coerção (ordinária e extraordinária) e a fraude. Mas a quem são endereçadas essas duas passagens? Ao príncipe (o homem de poder) e ao legislador. Para o primeiro, desconsiderar a necessidade significa arruinar-se. Menos do que o fundamento de seu poder, o que está em jogo é sua conservação. Para o segundo, a lei perde sua razão de ser caso os homens sejam bons. A lei se prende, portanto, à lógica da necessidade, resultando ela própria da impossibilidade dos homens coexistirem em uma comunidade política sem alguma forma de coerção. Se a necessidade permite compreender as ações do príncipe e do legislador, ela não basta para explicar a grandezza de um estado. Roma, como exemplo de república, não é compreensível sem a introdução de outros elementos (o amor pela pátria, o desejo de liberdade) que, se não estão no fundamento, fazem parte da dinâmica política.

\section{Conclusão}

Que republicanismo podemos depreender então a partir dessa leitura de Maquiavel? Acredito que seu elemento popular tenha mais uma vez sido destacado e espero que suas críticas àqueles que menosprezam a competência política do povo (como vemos no capítulo XI de O príncipe e no 58 do livro I dos Discursos) tenham ganhado um pouco mais de precisão. A competência a que me refiro aqui não concerne especialmente à faculdade judicativa, quero dizer, cognitiva do povo (embora Maquiavel deixe claro em Discursos, I, 4, 47 e 48 que os homens em geral julgam bem quando conhecem as particularidades dos acontecimentos ${ }^{23}$ ), mas a seu papel mesmo como agente político, como guardião da liberdade.

O cumprimento dessa função requer que o desejo do povo adquira alguma positividade, não podendo se reduzir ao contrário do desejo dos grandes. Isso significa também que a articulação entre interesse pessoal e interesse público merece ser reavaliada. Via de regra, os intérpretes de Maquiavel entendem que o motivo primeiro que leva os homens a defenderem a liberdade é que essa é a garantia de que eles poderão satisfazer seus interesses privados. Ora, essa perspectiva está necessariamente vinculada a uma con-

23 Uma perspectiva ciceroniana, como vemos no De amicitia, XXV, 95, o que é reconhecido pelo próprio Maquiavel. 
cepção negativa da liberdade e do desejo do povo. A liberdade aparece como negativa porque consistiria em ausência de dominação. O desejo do povo é concebido negativamente porque é aquilo que há de comum na diversidade de interesses pessoais dos cidadãos: não ser dominado por outrem. Por fim, é a própria concepção de virtù que acaba por ser compreendida também de forma negativa, pois consistirá, quando referida ao povo, na disposição para a ação cuja finalidade é evitar a dominação. Neste trabalho tentei mostrar que essa abordagem do pensamento de Maquiavel encontra um grande obstáculo: contamina seu republicanismo com um pressuposto teórico, desenvolvido posteriormente na história do pensamento político, segundo o qual no fundamento da vida pública vamos encontrar os interesses privados, sendo que a busca por sua satisfação orientaria a dinâmica política. Quando aplicamos esse pressuposto torna-se difícil apreender a natureza de seu republicanismo e perde-se de vista seu caráter exigente e austero.

ADVERSE, Helton. Maquiavel, the republic and the desire of freedom. Trans/Form/ Ação, (São Paulo), v.30(2), 2007, p.33-52.

- ABSTRACT: The aim of the article is to understand some aspects of the Machiavelli's republicanism granting attention to his theory of the umori. More specifically, my purpose can be summarized as understanding the nature of the "desire of the people" and its role in the political life. The main hypothesis of this work is that the function that Machiavelli attributes to the people, the guardian of the freedom, demands, for its execution, the active participation of the citizen in the civic tasks, that is, his inscription in the public space as a political agent. That inscription cannot be understood entirely if the desire that characterizes the people lacks of any determination, that is, if it be only taken in a negative perspective.

- KEYWORDS: Machiavelli; republic; freedom, desire of the people; vivere civile.

\section{Referências bibliográficas}

ABENSOUR, M. A democracia contra o estado. Marx e o momento maquiaveliano. trad. de C. P. B. Mourão, C. F. Santiago, E. D. Galéry. Belo Horizonte: Editora UFMG, 1998.

BARON, H. The crisis of the Early Italian Renaissance. Princeton: Princeton University Press, 1966 (2 edição).

In search of Florentine Civic Humanism. Princeton: Princeton University Press, 1988.

BOCK, G. "Civil Discord in Machiavelli's Istorie Fiorentine". In G. Bock, Q. Skinner e M. Viroli (org), Machiavelli and republicanism. Cambridge: Cambridge University Press, 1990, p.181-201. 
FISCHER, M. Well-ordered license. On the unity of Machiavelli's thought. Nova York: Lexington Books, 2000.

FOUCAULT, M. Sécurité, territoire, population. Cours au Collège de France, 19771978. Paris: Gallimard/Seuil, 2004.

GAILLE-NIKODIMOV, M. Conflit civil et liberté. La politique machievélienne entre histoire et médecine. Paris: Honoré Champion, 2004.

HÖRNOVIST, M. Machiavelli and empire. Cambridge: Cambridge University Press, 2004.

LARIVAIILE, P. "Chapitre Neuf du Prince. La Crise de la Principauté Civile" in T. Ménissier e Y. C. Zarka, Machiavel, le prince et le nouvel art politique. Paris: PUF, 2001, p.81-103.

LEFORT, C. Le travail de l'œuvre Machiavel. Paris: Gallimard, 1972.

"Machiavel: La Dimension Économique du Politique". In Les formes de l'histoire. Paris: Gallimard, 1978.

MANSFIELD, H. C. Machiavelli's virtue. Chicago: The University of Chicago Press, 1996.

MAQUIAVEL, N. Il principe. In Tutte le opere. Org. por M. Martelli. Florença: Sansoni, 1993a (2 edição).

Discorsi sopra la prima deca di Tito Livio. In Tutte le opere. Org. por M. Martelli. Florença: Sansoni, 1993b (2 edição).

Istorie fiorentine. In Tutte le opere. Org. por M. Martelli. Florença: Sansoni, 1993c (2 edição).

MÉNISSIER, T. “Qu'est-ce que la Vertu Républicaine? Quelques Remarques sur l'Interprétation de Machiavel dans Le moment machiavélien. In M. Senellart e G. Sfez (org) L'enjeu Machiavel. Paris: Puf, 2001, p.241-6.

"République, Ordre Collectif et Liberté" in M. Gaille-Nikodimov e T. Ménissier, Lectures de Machiavel. Paris: Ellipses, 2006, p.151-91.

NADEAU, C. "Machiavel. Domination et Liberté Politique". In Philosophiques, 30/2. Outono de 2003, p.321-51.

POCOCK, J. G. A. The Machiavellian moment. Princeton: Princeton University Press, 1975.

RAHE, P. "Situating Machiavelli". In J. Hankins, Renaissance Civic Humanism - Reappraisals and reflections. Cambridge: Cambridge University Press, 2000, p.270-308.

SASSO, G. Machiavelli e gli antichi e altri saggi. Milão e Nápoles: Riccardo Ricciardi Editore, 1987-97, 4 volumes.

SFEZ, G. Machiavel, la politique du moindre mal. Paris: PUF, 1999.

SKINNER, Q. As fundações do pensamento político moderno. Trad. de R. J. Ribeiro. São Paulo: Companhia das Letras, 1996.

. Liberdade antes do liberalismo. Trad. de R. Fiker. São Paulo: Unesp, 1998.

"The Idea of Negative Liberty: Machiavellian and Modern Perspectives".

In Visions of politics. Vol. II: Renaissance virtues. Cambridge: Cambridge University Press, 2002, p.186-212. 
SULLIVAN, V. Machiavelli, Hobbes and the formation of a liberal republicanism in England. Cambridge: Cambridge University Press, 2004.

TITO LÍVIO Histoire romaine. Trad. de A. Flobert. Paris: Flammarion, 1995.

VIROLI, M. Per amore della patria. Patriottismo e nazionalismo nella storia. Roma: Laterza, 2001.

ZARKA, Y. C. "L'Amour de la Patrie chez Machiavel". In Figures du pouvoir. Études de philosophie politique de Machiavel à Foucault. Paris: PUF, 2001, p.13-26. 